\title{
SPRAWA PUBLIKACJI UCHWAL PIERWSZEGO SYNODU PROWINCJALNEGO KARD. KAROLA BOROMEUSZA
}

Program reformy i odnowy Kościoła, nakreślony w uchwałach soboru trydenckiego, stał się doniosłą inspiracją w reformatorskiej działalności kard. Karola Boromeusza (1538 - 1584) jako arcybiskupa-metropolity mediolańskiej prowincji kościelnej. Podstawowym krokiem na drodze reform w tej metropolii, obejmującej 16 diecezji, powziętym przez wybitnego rzecznika odnowy trydenckiej, stał się jego pierwszy synod prowincjalny, odbyty w Mediolanie w dniach 15 X - 3 XI 1565 r. Owocem obrad tego zgromadzenia były obszerne statuty synodalne zawarte w 94 nie numerowanych, lecz zaopatrzonych w rubryki artykułach ${ }^{1}$. Zaprezentowany w nich reformatorski program odnowy podupadłego życia religijno-moralnego prowincji kościelnej regulował w duchu soborowym całokształt spraw nurtujących wówczas tę jednostkę administracyjną.

Wejście w życie statutów synodu z 1565 r. z natury rzeczy uwarunkowane było uprzednią ich publikacją. Ta zaś, z uwagi na szczególne okoliczności związane ze stanowiskiem władzy świeckiej, nastręczyła kard. Boromeuszowi niemałych trudności.

\section{ZABIEGI KARD. BOROMEUSZA O APROBATĘ PAPIESKĄ DLA STATUTÓW}

Wprawdzie dopiero 14 VI 1573 r. Kongregacja Soboru poleciła, aby nie publikować uchwał synodów prowincjalnych przed zasięgnięciem jej rady, a bulla Sykstusa V Immensa aeterni z 22 I 1588 r. wymagała uprzedniego formalnego rozpoznania statutów przez tę kongregację ${ }^{2}$, to jednak już od 1565 r. zaczęła

${ }^{1}$ Constitutiones et decreta condita in provinciali synodo Mediolanensi prima, [w:] Acta Ecclesiae Mediolanensis, [wyd. A. Ratti], t. 2, Mediolani MDCCCXC, kol $29-156$. W następnych przypisach cytuję to dzielo - AEM.

2 ,Et quoniam eodem Concilio Tridentino decretum est synodos provinciales tertio quoque anno, dioecesanas singulis annis celebrari debere, id in executionis usum ab iis, quorum interest, induci eadem congregatio providebit. Provincialium vero, ubisvis terrarum illae celebrentur, de- 
się kształtować praktyka samorzutnego wysyłania przez metropolitów do tejże kongregacji statutów synodów prowincjalnych. Chodziło o upewnienie się w ten sposób, czy są one zgodne z prawem soboru trydenckiego. Aprobata Rzymu nadawała ponadto uchwałom synodalnym odpowiednią rangę ${ }^{3}$.

Kard. Boromeusz, zdając sobie sprawę z trudności, na jakie mógł napotkać we wprowadzaniu w życie uchwał swojego synodu, postanowił uzyskać dla nich aprobatę samego Piusa IV 4 . Już jednak w 10 XI 1565 r., a więc w tydzień po zakończeniu zgromadzenia synodalnego metropolita mediolański zmuszony był opuścić Mediolan i udać się, stosownie do polecenia papieskiego, wyrażonego w liście z $27 \mathrm{X}$, do Trydentu, celem powitania tam sióstr cesarza Maksymiliana II — księżniczek Barbary i Joanny, oraz przeprowadzenia ważnych negocjacji ${ }^{5}$. Na wiadomość o ciężkiej chorobie Piusa IV arcybiskup wyjechał pośpiesznie do Rzymu, gdzie zastał jeszcze swego wuja przy życiu. Po jego śmierci, która nastąpiła 9 XII 1565 r., kard. Boromeusz wziął udział w konklawe, które 7 I 1566 r. wybrało papieżem kard. Michała Ghislieri (Pius V). W Rzymie metropolita pozostał do 11 III $1566 \mathrm{r}^{6}$

Egzemplarz statutów synodu mediolańskiego został prawdopodobnie przesłany do Rzymu przez kancelarię kard. Boromeusza podczas jego pobytu w Trydencie lub Rzymie. Bezpośrednio po zakończeniu synodu Mikołaj Ormaneto, wikariusz generalny arcybiskupa, dokonał zapewne jeszcze pewnych udoskonaleń redakcyjnych w niektórych artykułach statutów. Wolno przyjąć, że tekst tych ostatnich dotarł do Rzymu podczas choroby Piusa IV, a może nawet po jego zgonie. Udzielenie aprobaty zbiorowi mediolańskiemu zostało tym samym uzależnione od decyzji Piusa V? .

Tymczasem zdecydowana niechęć gubernatora hiszpańskiego Gabriela de la Cueva (księcia Albuquerque) oraz senatu mediolańskiego, żywiona wobec niektórych postanowień synodu prowincjalnego, godzących w uzurpowane so-

creta ad se mitti praecipiet, eaque singula expendet et recognoscet" (Magnum Bullarium Romanum, t. 8, Augustae Taurinorum 1863, s. 991).

${ }^{3}$ P. Hin s chi u s, System des katholischen Kirchenrechts, Graz 1959, s. 648; zob. także: I. S u b e ra, Synody prowincjonalne arcybiskupów gnieźnieńskich, Warszawa 1971, s. 141; W. Wój ci k, Ze statutów nad synodami polskimi, Lublin 1982, s. 167 - 168.

${ }^{4} \mathrm{P}$. P ro di, Note sulla genesi del diritto nella Chiesa post-tridentina, [w:] Legge e Vangelo. Discussione su una legge fondamentale per la Chiesa, Brescia 1972, s. 210. Na temat owego zwracania się przez kard. Boromeusza o zatwierdzenie uchwał własnych synodów pisze P. Fagnani: „Quo loco omittendum non est, concilia provincialia Mediolanensia consuevisse approbari a Summo Pontifice per litteras in Forma Brevis, cum tamen alia provincialia concilia non confirmentur, sed tantummodo recognoscantur, et emendentur a S. Congragatione Concilii, ad praescriptum constitutionis Sixti V super institutione eiusdem congregationis" (E. F a g n a n i, Ius canonicum, t. 2, Venetiis 1709 , s. 8).

${ }^{5} \mathrm{E}$. Ca t t a n e o, Gli ostacoli posti dal senato milanese alla pubblicazione del $1^{\circ}$ concilio provinciale (a. 1565), Città del Vaticano 1964, s. 3; S. R. R y bi ck i, Święty Karol Boromeusz, wierny stuga Kościoła Odrodzenia (1538-1584), Kraków 1978, s. 76; Z. Mo r a w sk i, Św. Karol Boromeusz na tle odrodzenia religijnego w XVI wieku, Poznań-Warszawa 1922, s. 74; A. S a l a, Documenti circa la vita e le gesta di S. Carlo Borromeo, t. 1, Milano 1855, s. 166.

6 A. M a j o, San Carlo Borromeo, vita e azione pastorale, Milano 1984, s. 27 - 28.

${ }^{7}$ Zob. E. Cat t a n o, Gli ostacoli..., s. 4. 
bie przez nich od dawna prerogatywy ( $\mathrm{m}$. in. w zakresie nadawania beneficjów kościelnych), przerodziła się $\mathrm{w}$ formalną opozycję, przybierając na sile po śmierci Piusa IV, protektora Boromeusza. Gubernator ostro protestowal przeciwko niewygodnym mu dyspozycjom synodu argumentując, iż są one niezgodne z uprawnieniami króla hiszpańskiego Filipa II, w którego koronie znajdowało się państwo Mediolańskie. Senat mediolański zaś przedłożył nawet - poprzez swego przedstawiciela Piccinardi - specjalny protest skierowany do dworu madryckiego przeciwko statutom synodalnym. Opozycję gubernatora i senatu podsycała przy tym znaczna część kleru, wrogo usposobionego do wielu norm prawnych powziętych na synodzie ${ }^{8}$.

O wzrastającej opozycji przeciwko statutom synodalnym informował przebywającego poza diecezją arcybiskupa Mikołaj Ormaneto, m.in. w liście z 28 XI 1565 r. ${ }^{9}$ Dla kard. Boromeusza nie było to jednak zaskoczeniem; o pierwszych przejawach niechęci gubernatora i senatu do reformy trydenckiej dowiedział się bowiem już z listu swego oddanego wikariusza generalnego jeszcze podczas synodu diecezjalnego w r. 1564, gdy przebywał w Rzymie ${ }^{10}$.

Licząc się z realną możliwością stawiania przez władzę świecką przeszkód we wdrażaniu w życie uchwał synodu mediolańskiego, arcybiskup wystosował wkrótce po zakończeniu synodu stosowne memoriały zarówno do Madrytu, jak i do Rzymu, wyjaśniając charakter zgromadzenia synodalnego. Do króla przesłał jednocześnie sumariusz uchwał synodalnych; nie uczynił jednak tego przez pośrednictwo gubernatora, czego ten się spodziewał ${ }^{11}$. Senat mediolański tym skwapliwiej więc podejmował działania zmierzające do ignorowania synodu i utrudniania arcybiskupowi publikacji statutów synodalnych. Nie brakło $\mathrm{m}$. in. oskarżania metropolity u króla o naruszanie jurysdykcji królewskiej $^{12}$. Jednym z przejawów owej aktywności senatu był list z 28 XI 1565 r., adresowany do Filipa II. W liście tym wyrażono postulat, aby król polecił gubernatorowi i senatowi wydanie zakazu wykonywania postanowień synodu bez uprzedniego dokładnego zapoznania się przez senat ze statutami synodalny$\mathrm{mi}^{13}$. Jedynie interwencja agenta kard. Boromeusza - Tullio Albonese -

${ }^{8}$ S. R. Ry bicki, Swięty Karol Boromeusz, jw., s. 143; Zob. także L. Pros docimi, Controriforma e politica spagnola a Milano, „Echi di San Carlo Borromeo” 16(1938) z. 13, s. 503 - 504 oraz $536-537$.

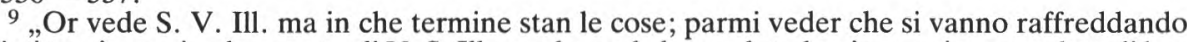
gl'animi tanti accesi nel cospetto di V. S. Ill. ma, la quale han voluto lasciar partire consolata di larghe promesse" (C. M a r co r a, Nicolò Ormaneto, Vicario di S. Carlo: giugno 1564 - giugno 1566, [w:] Memorie storiche della diocesi di Milano, t. 8, Milano 1961, s. 416).

${ }^{10} \mathrm{E}$. Cat t a neo, Gli ostacoli..., s. 6.

11 Zob. list kard. Alciati do kard. Boromeusza z 23 XI 1565 r.: „Nel resto mi occorre a dirle, se bene forse sarà tardo avviso, che se sin ad hora non ha datto al S. Don Gabriele il summario del Sinodo provinciale per mandarlo in Spagna" (Biblioteka Ambrozjańska, ms F. 36 inf. k. 690; dalej w skrócie: BA).

${ }_{12}$ Zob. L. Pros d o ci mi, La Chiesa milanese di fronte all'autorità politica nell' età dei Borromei, [w:] Cività di Lombardia - La Lombardia Spagnola, Milano 1984, s. 234.

${ }^{13},[. .$.$] che dia ordine al Signor Governatore et al Senoto, che non diano esecutione alle cose$ ordinate in questo concilio, se prima non son visti i decreti dal Senato, et ben examinati" (C. M a r cor a, Nicolò Ormaneto..., s. 417). 
sprawiła, że wysyłkę tego pisma odłożono ${ }^{14}$. Senat jednak skłaniał gubernatora, aby domagał się udostępnienia mu statutów synodu celem ich przestudiowania. Doszło do tego za sprawą Mikołaja Ormaneto, który obawiając się zaostrzenia konfliktu, przekazał senatowi sumariusz uchwał synodalnych ${ }^{15}$. Na ten gest wikariusz generalny metropolity mediolańskiego zdobył się tym chętniej, że liczył na poparcie w uznaniu statutów u senatora Jana Chrzciciela Rainoldi, życzliwie usposobionego do kard. Boromeusza ${ }^{16}$.

Senat mediolański po zapoznaniu się z sumariuszem statutów synodalnych wypowiedział się szczególnie krytycznie co do trzech dyspozycji: (1) wpisywania przez proboszczów do księgi stanu dusz grzechów, do których dany parafianin przejawiał skłonności; (2) uzyskiwania zgody biskupa na alienację dóbr kościelnych; (3) prowadzenia inwentarza dóbr kościelnych. Interwencje te Mikołaj Ormane ocenil jednak z dużą wyrozumiałością, o czym informował kard. Boromeusza w liście z 12 II 1566 r. ${ }^{17}$ Spodziewał się przy tym dalszych informacji w tym względzie od senatora Rainoldi, sądząc, że wszelkie zastrzeżenia senatu do statutów dobrze będzie poznać i wyjaśnić przed oddaniem ich do druku. Jak się okazało, Ormaneto liczył zbytnio na dobrą wolę senatu, nie uświadamiając sobie w pełni, że jego członkowie nieprzychylnie ustosunkowali się nie tyle do sformułowań niekórych uchwał synodu, ile raczej do samej reformy, którą statuty próbowały wprowadzać w życie. Patrycjuszom mediolańskim nie na rękę było szereg „nowości” synodu, które odbijały się zdecydowanym echem soboru trydenckiego ${ }^{18}$.

Tymczasem przebywający w Rzymie kard. Boromeusz uzyskawszy prywatne zatwierdzenie statutów swego synodu od papieża Piusa V, zabiegal - przez kongregację dla wykonania i przestrzegania reform soboru trydenckiego o ich urzędową aprobatę ${ }^{19}$. $\mathrm{O}$ aprobatę tę arcybiskup prosił papieża, mając m. in. na względzie to wszystko, co zaszło podczas jego nieobecności w Mediolanie. Zwrócił się więc o wystawienie i skierowanie do kanclerza mediolańskiego oraz do samego senatu odnośnych dokumentów papieskich, w których papież zachęciłby to kolegium do udzielenia poparcia w wykonaniu postanowień synodu prowincjalnego. Żądane dokumenty zostały podpisane 3 IV 1566 r., gdy

${ }^{14}$ Zob. list Albonese do kard. Boromeusza z 28 XI 1565 r. (BA ms F. 36 inf. k. 729).

15 Zob. list Albonese do kard. Boromeusza z 19 XII 1565 r. (BA ms. F. 106 inf. k. 558); zob. także listy Ormaneto do kard. Boromeusza z 19 XII 1565 r. i 6 I 1566 r. (C. M a r co r a, Nicolò Ormaneto..., s. 429,451$)$.

16 Zob. list Albonese do kard. Boromeusza z 7 II 1566 r.: „Il sommario che mandò V. S. Ill. ma delli decreti dello Sinodo provinciale in mano a Mons. Vicario, nel modo che haverà inteso dal medesimo signor vicario, è capitato nel senato e per la buona sorte nelle mani signor Raynoldo, qual credo che debbi haver fatto rellatione tale, che detto senato ne sii restato sodisfatto" (BA ms 107 inf. k. 144).

${ }^{17}$ Zob. C. M a r cor a, Nicolò Ormaneto..., s. 454-455.

${ }^{18}$ E. Ca t t a n e o, Gli ostacoli..., s. 10 - 11; tenże, Carnevale e Quaresima nell' età di S. Carlo Borromeo, „Ambrosius” 34 (1958) s. 51 - 73.

${ }^{19}$ Gdy chodzi o nazwę kongregacji zob.: E. Szt a frow s ki, Kuria Rzymska, Warszawa 1981, s. $120-121$. 
Boromeusz opuściwszy 11 III Rzym znajdował się w drodze do Mediolanu, dokąd przybył $5 \mathrm{IV}^{20}$.

W brewe skierowanym do senatu Pius V nadmienił, iż kard. Boromeusz, stosownie do polecenia soboru trydenckiego, odbył synod prowincjalny, którego owocem są liczne i bardzo pożyteczne dla prowincji kościelnej postanowienia. Winny być one wcielone w życie, co wymaga, dodał papież, pomocy senatu, w której udzielenie ufa ${ }^{21}$.

Dnia 7 IV kard. Boromeusz skierował list do Filipa II, informując go o pomocy w realizacji statutów synodalnych, udzielonej mu przez Rzym oraz prosząc o skłonienie gubernatora i senat mediolański do niesienia pomocy władzom kościelnym w rozwijaniu pobożnych dzieł na rzecz miasta, jak również w przestrzeganiu postanowień statutów synodu, które wkrótce zostaną oddane do druku ${ }^{22}$. Jednocześnie arcybiskup wystosował specjalny list do nuncjusza papieskiego w Hiszpanii, prosząc o interwencję u króla w tej samej sprawie ${ }^{23}$.

Tymczasem opozycja przeciwko publikacji statutów synodu kard. Boromeusza nie ustawała. Gubernator szukał coraz to nowych pretekstów do wystąpień przeciwko arcybiskupowi. Tak np., gdy przekonany przez osoby wrogo usposobione Boromeuszowi, że ten ostatni, nie będąc już legatem papieskim na całą Italię, winien mu - jako reprezentantowi króla — odstąpić swoje miejsce w katedrze, wyraźnie zgłosił takie roszczenie, mimo odmiennego stanowiska Boromeusza ${ }^{24}$.

Nie czekając na papieską aprobatę statutów synodu mediolańskiego, metropolita domagał się coraz bardziej stanowczo stosowania się do nich. Znaczną pomocą były dlań tutaj trzy kolejne brevia papieskie, które wyszły z kancelarii Piusa V w kwietniu i maju 1566 r. Tak więc breve z 11 IV zezwalało kard. Boromeuszowi interweniować wszędzie, również w klasztorach, w sprawie przestrzegania statutów synodalnych ${ }^{25}$. Dokument z 19 IV aprobował z kolei podejmowanie działań zmierzających do wypełnienia postanowień dotyczą-

${ }^{20}$ E. Catta ne o, Gli ostacoli..., s. 11.

21 „Etsi autem confidimus nos, etiam sine hortatione nostra, ad eas exequendas, vestrum, quandocumque opus fuerit, auxilium, propense esse impertituros: tamen petimus vobis, ac studiose requirimus: ut id pro nostra et sedis Apostolicae reverentia, etiam propensius, quotiescumque opus fuerit, et petitum impertiatis" (E. Ca t t a n e o, Gli ostacoli..., s. 11).

22 „Ma sapendo io questo sia importante la continua protettione di V. Mtà et la rinovatione de gli ordini suoi, havendone fatto supplicare V. Mtà per mezzo de l'Ambasciadore suo, torno a supplicarla con la presente, che si degni di haver a cuore le cose di questa Chiesa, et aiutare il scopo, et questa sola mira del servitio di Dio, et de la salute di queste anime, commettendo, che questi suoi ministri qui aiutino tuttavia et favoriscano la dignità et auttorità ecclesiastica sopra tutto il buon progresso di tutte le opere pie di questa città, et l'osservatione spetialmente del Sinodo Provinciale; che presto, piacendo $\mathrm{a}$ Dio, si darà e la stampa: et in somna, che mi dieno tutto l'aiuto che mi farà bisogno, per il buon governo di questa Chiesa" (BA ms F. 37 inf. k. 109-110).

23 Tamże, k. 84.

${ }^{24}$ Spór gubernatora de la Cueva z kard. Boromeuszem o pierwsze miejsce w katedrze przedłużał się. Nie obeszło się bez odniesienia się do Rzymu i do Madrytu. Ostatecznie król sugerował gubernatorowi, aby nie bral udziału w ceremoniach, podczas których miałaby wyniknąć sprawa precedencji; zob. E. Catt a ne o, Gli ostacoli..., s. 12-13.

25 AEM t. 3 kol. 1395 - 1401. 
cych prowadzenia seminariów duchownych ${ }^{26}$. Wreszcie pismo z $24 \mathrm{~V}$ zatwierdzało obowiązek przeprowadzania egzaminu dla wszystkich kandydatów do święceń27.

\section{UDZIELENIE APROBATY PAPIESKIEJ}

Ukoronowanie wymienionych wyżej dokumentów papieskich stanowiła bulla Piusa V Inter omnes, wystawiona 6 VI 1566 r., zatwierdzająca statuty synodu prowincjalnego ${ }^{28}$. Na wstępie ten doniosły dla metropolity mediolańskiego dokument przypominał, iż odbył on synod prowincjalny, na którym wydano szereg statutów i dekretów, dotyczących przede wszystkim życia i obyczajów duchowieństwa. Postanowienia te są bardzo chwalebne i zasługują na respektowanie przez wszystkich. Następnie zawarte jest istotne stwierdzenie, iż papież zatwierdza wszystkie statuty i dekrety synodu, które należy wydać drukiem i opublikować, oraz poleca, by przez wszystkich były dokładnie przestrzegane pod karami ustanowionymi przez sobór trydencki oraz innymi sankcjami świętych kanonów. Dokument powołuje się przy tym na ustne zreferowanie uchwał synodalnych papieżowi przez kard. Boromeusza. Zobowiązując do podporządkowania się uchwałom synodalnym, papież wymienia expressis verbis wszystkie kościoły, klasztory, prepozytury, szpitale i inne pobożne miejsca świeckie i zakonne, nawet poddane bezpośrednio Stolicy Apostolskiej, tj. wyjęte spod jurysdykcji biskupa. Wymienia poza tym osoby związane statutami i dekretami synodu: prałatów, opatów, przeorów, prepozytów, rektorów, przełożonych, duchownych, kapituły, kanoników, osoby świeckie, notariuszy, akolitów, kapelanów, urzędników Kurii Rzymskiej, członków dworu papieskiego łącznie z kardynałami.

W dalszym ciągu bulla zawiera polecenie skierowane do biskupów oraz innych przełożonych dotyczące publikacji uchwał synodu i wydania nakazu stosowania się do nich. Jeśliby zaś, dodaje dokument, uchwały te, mimo upomnienia udzielonego przez ordynariusza nie były przez zainteresowanych, $\mathrm{m}$. in. przez biskupów, egzekwowane i zachowywane, to takie zaniedbanie winien uzupełnić metropolita lub jego wikariusz generalny, stosując przy tym sankcje karne.

Pierwsza z klauzul końcowych, skierowana do sędziów, komisarzy i kardynałów, sankcjonowała nieważność wszelkich rozstrzygnięć opartych na fałszywej interpretacji owej wzmianki o stosowaniu kar. Inna klauzula końcowa pro-

${ }^{26}$ Tamże, kol. $1404-1405$.

27 Tamże, kol. $1405-1407$.

${ }^{28}$ Confirmatio statutorum et ordinationum in synodo provinciali Mediolanensi circa mores personarum ecclesiasticarum eiusdem provinciae, [w:] Bullarium magnum Romanum, t. 7, Augustae Taurinorum 1862, kol. 458-461; AEM t. 3 kol. 1407-1410; A. D e r o o, S. Carlo Borromeo cardinale riformatore, Milano 1965, s. 253; A. Ma jo, Storia della Chiesa ambrosiana, t. 2: Dall'età comunale a Carlo Borromeo, Milano 1983, s. 234. 
klamowała obowiązywalność postanowień bulli bez względu na jakiekolwiek przeciwne jej przywileje, zwyczaje, indulty, listy apostolskie.

Celem zdecydowanego zobowiązania osób zakonnych do przestrzegania uchwał synodu papież wystosował do kard. Boromeusza specjalne breve z 27 VI 1566 r. ${ }^{29}$ Polecił w nim, aby do statutów stosowały się wszystkie osoby zakonne, nawet wyjęte. Jednocześnie do metropolity skierował apel, aby dopilnował wprowadzenia w życie przez klasztory postanowień synodalnych w ciągu sześciu miesięcy. Po udzieleniu winnym upomnienia, które w ciągu kolejnych sześciu miesięcy okazałoby się nieskuteczne, metropolita winien powiadomić papieża, aby swoją interwencją mógł on skłonić opornych do podporządkowania się statutom. Klauzula końcowa uchylała wszelkie przywileje przeciwne postanowieniom breve.

Stosownie do omówionego wyżej breve, kard. Boromeusz wystosował w dniu 7 IX $1566 \mathrm{r}$. specjalny edykt skierowany do klasztorów z poleceniem, aby w ciągu sześciu miesięcy zastosowano się w nich do statutów synodu, pod sankcją, o której była mowa w breve ${ }^{30}$. Wraz z aprobatą statutów synodalnych arcybiskup otrzymał także polecenie publikowania niektórych bulli, m. in. Coenae Domini ${ }^{31}$.

\section{DRUK STATUTÓW}

Zatwierdzenie przez Piusa V uchwał synodu mediolańskiego stanowiło niewątpliwie doniosły moment, mający utorować drogę ku ich publikacji, a co za tym idzie - realizacji w życiu prowincji kościelnej. Był to zarazem duży sukces osobisty niezmordowanego arcybiskupa-metropolity. Aprobata papieska statutów synodalnych nie oznaczała jeszcze ich natychmiastowej publikacji. Zarówno gubernator, jak i senat mediolański zgłaszali tu w dalszym ciągu trudności i przeszkody. Z uwagi na częstą niedyspozycję księcia Albuquerque kard. Boromeusz nie mógł z nim pertraktować na temat owych zastrzeżeń ${ }^{32}$. Zdecydowana jednak i nieustępliwa postawa arcybiskupa przyniosła w końcu pożądany rezultat: gubernator i senat wyrazili zgodę na publikację zarówno uchwał synodu, jak i bull papieskich. Informował o tym z satysfakcją i uznaniem dla gubernatora kard. Boromeusz w liście z VII 1566 r., skierowanym do papie$\dot{z} \mathrm{a}^{33}$.

${ }^{29}$ AEM t. 3 kol. $1410-1412$.

30 Tamże, kol. 1412.

${ }^{31}$ E. Cat t a n e o, Gli ostacoli..., s. 13.

32 Tamże, s. 14.

33 „Scritto fin qui il Governatore m'ha rimandato il libro del sinodo ch'ha sipigliato dal Senato, facendomi intendere ch'io attenda pure a far l'officio mio, poichè egli non confida meno di me medesimo di Quel che faccia nel Senato e che nel detto sinodo fosse cosa che pregiudicasse alla giurisddittione temporale. Dal quale atto si può comprendere la pietà è buon zelo di quel signore" (BA ms P 1 inf. fasc. IV k. 68). 
Druk statutów synodalnych, przygotowany niewątpliwie wcześniej przez Ormaneto, został zrealizowany w Mediolanie w sierpniu 1566 r. Swiadczy o tym dekret doży weneckiego z 3 IX 1566 r., w którym — na prośbę kard. Boromeusza - zakazuje sprzedawania wydrukowanych uchwał synodu mediolańskiego, jak również kolejnego ich drukowania.przez najbliższe 3 miesiące bez zgody metropolity ${ }^{34}$. Edycja ta, tzw. duża $(21$ x $15 \mathrm{~cm})$ ukazała się pod następującym tytułem: Constitutiones et decreta condita in provinciali synodo mediolanensi sub Ill.mo et Rev.mo D.D. Carolo Borromeo [...], Mediolani MDLXVI, apud Jo. Baptistam et Pontios fratres ${ }^{35}$. Prawdopodobnie wkrótce po edycji oryginalnej, a może równolegle $\mathrm{z}$ nią, ukazało się drugie wydanie uchwał synodu, wykonane także w Mediolanie w $1566 \mathrm{r}$. Była to - pod tym samym tytułem - edycja tzw. mała $(15 \times 8 \mathrm{~cm}):[\ldots]$ Mediolani $M D L X V I$, apud Franciscum Seronum cum Privilegio ${ }^{36}$.

W pierwszych miesiącach $1567 \mathrm{r}$. ukazały się kolejne - trzecie i czwarte wydania uchwał synodalnych: jedno - w Wenecji (Venetiis Aldus), drugie w Bresci (apud Thomam Bozolam) ${ }^{37}$. Były to wydania poprawione ${ }^{38}$. Wymienione cztery edycje objęły łącznie swym nakładem 6000 egzemplarzy, co wówczas stanowiło imponującą cyfrę ${ }^{39}$.

Pierwsze egzemplarze uchwał swego synodu prowincjalnego kard. Boromeusz wysłał do Kongregacji dla wykonania i przestrzegania reform soboru trydenckiego. Przesyłka została przekazana na ręce Juliusza Poggiano, który w liście z 28 IX 1566 r. dziękował metropolicie mediolańskiemu za otrzymane tomy i zarazem prosił o więcej egzemplarzy ${ }^{40}$. Szereg egzemplarzy z pierwszych czterech edycji uchwał synodu arcybiskup przesłał biskupom głównych biskupstw Italii, a także proszącym o to biskupom z Niemiec, Polski, Francji, Hiszpanii, Portugalii. Informację tę zawiera list kard. Jana Franciszka Commendone z 18 X 1566 r. ${ }^{41}$

${ }^{34}$ A. Sala, Documenti..., t. 1 s. 186.

${ }^{35}$ E. Cat t a n e o, Gli ostacoli..., s. 250.

36 Tamże.

37 Tamże; zob. także tenże, La singolare fortuna degli „Acta Ecclesiae Mediolanensis”, „Scuola Cattolica" 111(1983) nr 3-4 s. 193.

${ }_{38}$ Zdaje się wskazywać na to przytoczony już wyżej dekret doży weneckiego z 3 IX 1566 r., w którym zakazuje - pod sankcją 100 dukatów - drukowania (na terenach mu podleglych) statutów synodalnych, gdyż kard. Boromeusz poszukiwał wówczas odpowiednich i uczciwych korektorów, a także dobrej oficyny wydawniczej, która by zrealizowała wydanie bardziej staranne i w lepszej formie; zob. A. S a la, Documenti..., t. 1 s. 186.

${ }^{39}$ E. Cat $\mathrm{t}$ a n e o, La singolare fortuna..., s. 193; A. M a jo, San Carlo Borromeo, vita e azione pastorale, Milano 1984, s. 75.

40 A. Sala, Documenti..., t. 1 s. $577-578$.

41 „I libri che V. S. m'ha mandato del Concilio Provinciale mi capitarono ieri in villa e di là ne mandai una parte a Venezia per darli a quei prelati che in Germania e in Polonia me ne hanno richiesto, a ciò che abbiano chie imitare nelle loro synodi" (E. Ca t t a n e o, Il primo concilio provinciale milanese. A. 1565, [w:] Il Concilio di Trento e la riforma tridentina. Atti del convegno storico internazionale. Trento - $2-6$ settembre 1963, t. 1, Roma - Freiburg - Basel - Barcellona Wien 1965, s. 251); zob. H. D. W o j ty s k a, L'influsso in Polonia e in Lituania, [w:] San Carlo e il suo tempo. Atti del Convegno Internazionale nel IV centenario della morte (Milano, 21 - 26 maggio 1984), t. 1, Roma 1986, s. 537 - 538; E. C a t t a n e o, La singolare fortuna..., s. 193, 199. 
Jednym z pierwszych adresatów, do których metropolita mediolański skierował kopię niewątpliwie pierwszej edycji statutów synodalnych, był Filip II. W liście z 13 IX 1566 r., towarzyszącym przesyłce, a skierowanym za pośrednictwem nuncjusza papieskiego w Hiszpanii, kard. Boromeusz zwrócił się do monarchy o pomoc we wprowadzeniu w życie postanowień zawartych w uchwałach synodalnych ${ }^{42}$. Powodem tej prośby o pomoc w wykonaniu statutów synodu była wiadomość, jaka doszła do arcybiskupa, iż niektórzy członkowie senatu mediolańskiego udali się do Madrytu w celu powzięcia nowej akcji przeciwko reformatorskim postanowieniom synodu. Boromeusz poinformował o tym niebezpieczeństwie nuncjusza w liście z 14 IX 1566 r., prosząc zarazem o wręczenie królowi wspomnianego pisma z 13 IX oraz o interwencję. $\mathrm{O}$ interwencję zaś u papieża prosil — w liście z $27 \mathrm{XI}$ — przebywającego już w Rzymie Ormaneto, informując swego dawnego wikariusza generalnego o wzrastającej opozycji senatorów przeciwko opublikowanym statutom synodalnym oraz bullom papieskim, zwłaszcza Coenae Domini. Uskarżał się przy tym arcybiskup na ciągłą tendencję senatu nieuznawania jego jurysdykcji ${ }^{43}$. Zwiastowało to głośny spór Boromeusza o jurysdykcję z senatem mediolańskim, zażegnany dopiero w $1583 \mathrm{r} .{ }^{44}$

Egzemplarze pierwszego wydania uchwał synodu mediolańskiego metropolita przesłał również do pozostałych panujących, od których zależne były diecezje wchodzące w skład prowincji kościelnej, a więc do księcia Savoi, księcia Mantui przedstawiciela republiki genueńskiej i doży weneckiego. Wysyłając statuty synodalne metropolita prosił jednocześnie każdego $\mathrm{z}$ władców o pomoc we wprowadzaniu ich w życie. Świadczy o tym m. in. list doży weneckiego Hieronima Priolo z 3 X 1566 r., stanowiący odpowiedź na pismo kard. Boromeusza. Władca wenecki, dziękując za kopię statutów, zapewnia arcybiskupa Mediolanu, iż wydał stosowne polecenia reprezentantom republiki weneckiej, aby udzielili swego poparcia w wykonaniu uchwał synodu prowincjalnego ${ }^{45}$.

Gdy chodzi o dalsze edycje statutów synodalnych, należy najpierw powiedzieć, iż od 1582 r. ukazywały się one łącznie ze statutami kolejnych pięciu sy-

42 „Essendomi finito di stampore il sinodo Provinciale, che de l'anno passato si celebrò in questa Metropoli di Milano, m' é parso di mandarlo, come fo, a la M.tà Vostra, per debito de la servitù et osservantia verso di lei; et per supplicarla, che così in questa come ne le città in questa Provincia sottoposte a la Mtà Vostra, si degni, conforme a la sua gran pietà et zelo, di favorirne l'essecutione a gloria di Dio, e a restauratione de la sua Chiesa $S$. ta, che questa è stata la principale et unica mira nostra nel celebrarlo" (BA ms P 1 inf. fasc. IV k. 201); zob. także C. M a r cor a, I primi anni dell'episcopato di S. Carlo (1566 - 1567), [w:] Memorie storiche della diocesi di Milano, t. 9, Milano 1963 , s. 572.

${ }^{43}$ BA ms F. 37 inf. k. 437; zob. także E. Cat t a n e o, San Carlo ed il momento storico, [w:] Ricerche storiche sulla Chiesa Ambrosiana, t. 13, Milano 1984, s. 25 - 28.

${ }_{44} \mathrm{Na}$ temat sporu o jurysdykcję zob.: L. Pros docimi, La Chiesa milanese, s. $229-248$; tenże, Riforma borromaica e conservatorismo politico. Dalle controversie di giurisdizione alla convergenza, [w:] San Carlo e il suo tempo..., t. 2 s. 691 - 708; A. G. G h ezzi, Conflitti giurisdizionali nella Milano di Carlo Borromeo: la visita apostolica di Gerolamo Ragazzoni nel 1575 - 76, Milano 1984.

${ }^{45}$ A. Sala, Documenti..., t. 1 s. 187. 
nodów prowincjalnych Boromeusza. Tego rodzaju kolekcje zostały wydane w 1582, 1601 i 1603 r. w Bresci, w 1583 r. w Mediolanie, w 1584 r. w Novarze, w 1595 r. w Cremonie, w 1595 i 1596 r. w Wenecji ${ }^{46}$. Następnie wypada dodać, że tekst uchwał pierwszego synodu prowincjalnego kard. Boromeusza znalazł się w dziele Acta Ecclesiae Mediolanensis, które ukazało się po raz pierwszy w $1582 \mathrm{r} .{ }^{47}$, powtórzone z powodu wyczerpania w $1583 \mathrm{r}$. Kolejne edycje tego zbioru, który zyskiwał sobie coraz to nowych odbiorców w Europie, zostały zrealizowane: 1599 r. w Mediolanie ${ }^{48}$, w 1603 r. w Bresci ${ }^{49}$, w 1643 r. w Paryżu ${ }^{50}$, w 1683 r. w Lyonie ${ }^{51}$, w 1738 r. w Bergamo ${ }^{52}$, w 1754 r. w Padwie ${ }^{53}$, w 1843 r. w Mediolanie ${ }^{54}$ oraz w latach $1890-1897$ w Mediolanie (Achilles Ratti) ${ }^{55}$. W sumie więc ukazało się aż dziewięć wydań Acta Ecclesiae Mediolanensis.

${ }^{46} \mathrm{E}$. Cat t a ne o, La singolare fortuna..., s. 197.

47 Acta Ecclesiae Mediolanensis tribus partibus distincta. Quibus concilia provincialia, conciones synodales, synodi dioecesanae, instructiones, litterae pastorales, edita, regulae confratriarum, formulae, et alia denique continentur, quae Cordus S. R. E. Cardinalis tit. S. Praxedis, Archiepiscopus egit. Cum privilegio Summi Pontificis, Romae MDLXXXII.

${ }_{8}$ Acta Ecclesiae Mediolanensis a Carlo Cardinali S. Praxedis archiepiscopo condita, Federici Borromei Archiepiscopi Mediolani iussu undique diligentius collecta et edita. Cum privilegio Summi Pontificis Mediolani. Ex officina Typographica quon. Pacifici Pontij impressoris Archiepiscopolis MDXCIX. Superiorum permissu.

${ }^{49}$ Acta Ecclesiae Mediolanensis a B. Carolo Borromeo S. R. E. Tit. S. Praxedis presbitero Cardinali Archiepiscopo, condita, Federici Card. Borromaei archiepiscopi Mediolani iussu undique diligentius collecta et edita. Addita est in hac ultima editione ipsius B. Caroli Cardinalis vita per Reverendiss. D. Carolum a Basilica Petri Novariensem episcopum confecta. Brixiae, Apud Societatem Brixiensem MDCIII. Superrio um permissu.

${ }^{50}$ Acta Ecclesiae Mediolanensis sive sancti Caroli Borromaei instructiones et decreta. In quibus De Ecclesiarum fabrica, suppellectile et ornatu; de Virorum Ecclesiasticorum dignitate, vita et officio; de politia Ecclesiastica, cultu divino, animarum regimine, et omnium hominum salute procuranda, pie, sancte ac cumulat praecipitur. Praeterea eiusdem sancti appendices septem: I. De cura pestilentiae. II. Sacramentale sive Sacramentorum administrandi ritus. III. Instructio Praedicationis Verbi Dei. IV. De mitore et munditia Ecclesiae. V. Institutio Seminarii: seu Clericorum instruendorum ratio. VI. De disciplina familiae Episcopalis, deque eius regimine. VII. Selecta quaedem Edicta, etmonita Christiana. Parisiis, Apud Joannem Jost, Via Jacobaea, sub signo Spiritus Sancti. MDCXLII. Cum privilegio Regis et approbatione Doctorum.

51 Acta Ecclesiae Mediolanensis a sancto Carolo cardinali S. Praxedis archiep. Mediolanen, condita, Federici cardinalis Borromaei archiepiscopi Mediolani jussu, undique diligentius collecta et edita. Editio nova, et emendatior, in qua quod in aliis Italice scriptum erat, latinitate donatum est. Lugduni, ex Officina Anissoniana et Joan Posuel. MDCLXXXIII. Cum privilegio Regis.

52 Acta Ecclesiae Mediolanensis a S. Carolo cardinali S. Praxedis archiepiscopo condita, Federici card. Borromaei archiepiscopi Mediolani iussu undique diligentius collecta et edita. Editio novissima. Addita septima Provinciali Syinodo. Bergomi MDCCXXXVII. Ex Typographia Ioannis Santini Superiorum permissu.

53 Acta Ecclesiae Mediolanensis a S. Carolo cardinali S. Praexedis archiepiscopo condita, Federici Borromaei archiepiscopo Mediolani jussu undique diligentius collecta, et postrema hac editione aucta. Patavii, Typis Seminarii. MDCCLIV. Apud Joannem Manfrè. Superiorum permissu et privilegio.

${ }_{54}$ Acta Ecclesiae Mediolanensis a sancto Carolo cardinali S. Praxedis archiepiscopo condita Federici Cardinalis Borromaei archiepiscopi Mediolani iussu undique diligentius collecta, Carolo Cajetano archiepiscopo cardinali De Gaisruck adprobante rursus edit. Mediolani MDCCCXLIII.

55 Acta Ecclesiae Mediolanensis ab eius initiis usque ad nostram aetatem, opera et studio presb. Achillis Ratti sacrae theologiae, juris canonici et philosophiae doctoris e collegio doctorum Bibliothecae Ambrosianae, cum approbatione Aloysii Nazari Comitis a Calabiana archiepiscopi mediolanensis. Mediolani MDCCCXC [t. 2], MDCCCXCII [t. 3], MDCCCXCVII [t. 4]. Tom pierwszy nie ukazal się; zob. G. G a lbi a ti, Papa Pio XI, Milano 1939, s. 184, 246, 265. 
Przyjęte przez pierwszy synod prowincjonalny kard. Karola Boromeusza obszerne uchwały w postaci statutów, regulujące w duchu soboru trydenckiego cały szereg dziedzin życia kościelnego, od samego początku wywoływały niechęć, a nawet sprzeciw gubernatora królewskiego oraz senatu mediolańskiego, skupiającego przedstawicieli miejscowego patrycjatu. Wzrastająca opozycja tych organów władzy przeciwko reformatorskim postanowieniom synodu znajdowała przy tym zdecydowane poparcie licznej grupy duchowieństwa, niezadowolonej $\mathrm{z}$ wielu rozwiązań zawartych $\mathrm{w}$ ustawodawstwie synodalnym. Przeciwstawiając się publikacji statutów synodalnych, zarówno przedstawiciele władzy kościelnej, jak i duchowieństwo, mieli w tym swój interes życiowy. Zaakceptowanie reformistycznych postanowień synodalnych przez senat oznaczało pogodzenie się $z$ utratą szeregu korzystnych prerogatyw, związanych $\mathrm{m}$. in. z prowizją na urzędy i beneficja, sądownictwem, kultem i nauczaniem. Przyjęcie synodu przez kler miało być równorzędne z zerwaniem przezeń ze stylem życia odbiegającym od wymogów postawionych w Trydencie.

Opozycja czynnika świeckiego oraz duchowieństwa przeciwko postanowieniom pierwszych synodów potrydenckich znana była i w innych środowiskach, m. in. we Francji, Hiszpanii czy Portugalii. Tytułem przykładu wystarczy wspomnieć, że zarówno statuty synodu diecezjalnego z 1564 r., jak i prowincjaInego $\mathrm{z}$ lat 1566 - $1567 \mathrm{w}$ Bradze (Portugalia) wywołały ostre protesty i sprzeciw przeciwko ich autorowi, biskupowi Bartłomiejowi des Martyrs, zdecydowanemu rzecznikowi reformy trydenckiej ${ }^{56}$.

W kontekście owej kontestacji norm synodalnych w środowisku mediolańskim stają się zrozumiałe zabiegi kard. Boromeusza o uzyskanie zatwierdzenia papieskiego dla uchwał synodu. Właściwych wymiarów nabierają również interwencje arcybiskupa Mediolanu u króla hiszpańskiego oraz postawa pewnego kompromisu w stosunku do gubernatora królewskiego, przejawiana przez Mikołaja Ormaneto, niestrudzonego i oddanego współpracownika metropolity. Uzyskanie aprobaty Piusa V dla uchwał synodu przyspieszyło niewątpliwie zgodę gubernatora i senatu mediolańskiego na publikację uchwał synodu i bull papieskich. Wydanie w sierpniu 1566 r. drukiem jednych i drugich oznaczało początek zwycięstwa kard. Boromeusza, choć nie było ono jeszcze przesądzone. Długotrwały konflikt z senatem o jurysdykcję miał się wszakże dopiero rozpocząć. Duży nakład pierwszych edycji statutów synodalnych, odpowiadający ówczesnym potrzebom, a następnie kolejne ich wydania, rozchodzące się szeroko poza granicami Italii, nie tyle zapowiadały, co raczej potwierdzały duży sukces ustawodawstwa „karolińskiego”.

56 Zob. R. de Almeida Rolo, L'application de la rèforme du Concile de Trente à Braga, [w:] Il Concilio di Trento e la riforma tridentina ..., t. 2, s. 555 - 576. 


\section{LA PUBBLICAZIONE DEI DECRETI DEL PRIMO SINODO PROVINCIALE DEL CARD. CARLO BORROMEO}

\section{Riassunto}

Il primo passo nella lunga strada verso l'applicazione della riforma tridentina nella provincia ecclesiastica di Milano (composta da 16 diocesi) fu il primo sinodo provinciale del card. Carlo Borromeo, arcivescovo di Milano, celebrato nei giorni 15 ottobre -3 novembre 1565 , accuratamente preparato da molto tempo. Il risultato della assamblea sinodale, svolta nella cattedrale milanese, furono i 94 decreti (statuti) sinodali in cui il legislatore provinciale aveva programmato la riforma ecclesiastica abbraciante i diversi campi della vita della metropolia ambrosiana.

Poco dopo il sinodo il senato milanese e il governatore don Gabriel de la Cueva, rappresentante del re di Spagna Filippo II a Milano, svolsero l'azione contro la pubblicazione dei decreti del sinodo provinciale. Si trattava di una opposizione suscitata dalle diverse disposizioni sinodali con i quali il card. Borromeo combatteva gli inveterati abusi ecclesiastici con tanti poteri di coloro che ne beneficiavano, tanto più se si considera che alcuni dei suoi provvedimenti non sfuggivano all'accusa, anche dalla parte del clero, di eccesivo rigorismo.

Rendendosi conto della resistenza contro i decreti del suo sinodo l'arcivescovo di Milano iniziò gli sforzi per ottenere l'approvazione pontificia dei suddetti decreti. Nello stesso tempo il Borromeo invió un memoriale al re Filippo IV insieme con la copia dei decreti sinodali, esplicando il carattere dell'assamblea sinodale. Il senato milanese si adoperava per ottenere dal re la proibizione della pubblicazione dei decreti sinodali. Essendo in quel tempo a Roma il card. Borromeo ottenne l'approvazione dei decreti dalla parte del papa Pio V (6 VI 1566), quindi si rivolse al Filippo II chiedendogli l'intervento con il quale il governatore e il senato di Milano aiutassero le autorità ecclesiastiche nella realizzazione delle disposizioni sinodali.

L' approvazione pontificia dei decreti del sinodo nonchè l'atteggiamento intransigente del arcivescovo di Milano verso l' opposizione provocarono finalmente che il governatore e il senato di Milano concessero l'accordo per la pubblicazione dei decreti sinodali.

La stampa dei decreti del sinodo del 1565 fu realizzata nel 1566 a Milano. Le ulteriori edizioni uscirono negli anni: 1566 (bis), 1567 (due volte), 1582, 1583, 1584, 1595, 1596, 1599, 1612, 1603 (due volte), 1643, 1683, 1738, 1754, 1843, 1890. 